\title{
Larkinella bovis sp. nov., isolated from fermented bovine products, and emended descriptions of the genus Larkinella and of Larkinella insperata Vancanneyt et al. 2006
}

Correspondence

Rangasamy Anandham

anandhamranga@rediffmail.com
Rangasamy Anandham, ${ }^{1,2}$ Soon-Wo Kwon, ${ }^{3}$ Hang-Yeon Weon, ${ }^{3}$ Soo-Jin Kim, ${ }^{3}$ Yi-Seul Kim, ${ }^{3}$ Pandiyan Indira Gandhi, ${ }^{4}$ Yong Ki Kim ${ }^{1}$ and Hyeong Jin Jee ${ }^{1}$

${ }^{1}$ Organic Agriculture Division, National Academy of Agricultural Science, Rural Development Administration, Suwon 441-707, Republic of Korea

${ }^{2}$ Department of Agricultural Microbiology, Agricultural College and Research Institute, Tamil Nadu Agricultural University, Madurai 625 104, Tamil Nadu, India

${ }^{3}$ Korean Agricultural Culture Collection (KACC), National Agro Biodiversity Center, National Academy of Agricultural Science, Rural Development Administration, Suwon 441-707, Republic of Korea

${ }^{4}$ Regional Research Station, Tamil Nadu Agricultural University, Vriddhachalam 606001, Tamil Nadu, India

A novel bacterial strain, designated $\mathrm{M} 2 \mathrm{~T}_{2} \mathrm{~B} 15^{\top}$, was isolated from fermented bovine products and was characterized by using a polyphasic approach. Colonies were reddish pink and circular with entire margins. Cells were strictly aerobic, Gram-reaction-negative, oxidase- and catalasepositive rods that lacked flagella and were motile by gliding. Flexirubin-type pigments were absent. 16S rRNA gene sequence analysis indicated that strain $\mathrm{M} 2 \mathrm{~T}_{2} \mathrm{~B}_{15}{ }^{\top}$ was related most closely to Larkinella insperata LMG $22510^{\top}$ ( $94.4 \%$ similarity) but shared $<87 \%$ similarity with other members of the phylum Bacteroidetes. The major cellular fatty acids were $C_{16: 1} \omega 5 c$, iso- $C_{15: 0}$ and iso- $\mathrm{C}_{17: 0} 3-\mathrm{OH}$. The polar lipids were phosphatidylethanolamine, phosphatidylserine, two unidentified aminophospholipids and two unidentified polar lipids. Menaquinone 7 (MK-7) was the major respiratory quinone. The $\mathrm{G}+\mathrm{C}$ content of the DNA of strain M2T2B15 ${ }^{\top}$ was $52 \mathrm{~mol} \%$. The phenotypic, genotypic and phylogenetic data presented clearly indicate that strain M2T2B15 ${ }^{\top}$ represents a novel species of the genus Larkinella, for which the name Larkinella bovis sp. nov. is proposed. The type strain is M2T2B15 ${ }^{\top}$ (=KACC $14040^{\top}=$ NBRC $\left.106324^{\top}\right)$. Emended

descriptions of the genus Larkinella and of Larkinella insperata Vancanneyt et al. 2006 are also proposed.
Panchakavya is a natural fertilizer prepared by organic farmers in Tamil Nadu, India, and is used widely for various agricultural and horticultural crops. Panchakavya is a combination of five products [dung, urine, milk, yogurt and ghee (clarified butter)] obtained from cows. Application of Panchakavya has significantly increased the yield of maize, sunflower and greengram and has increased crop resistance to pests and diseases (Belina et al., 2005; Somasundaram et al., 2007). To the best of our knowledge, no previous studies have addressed the

The GenBank/EMBL/DDBJ accession number for the 16S rRNA gene sequence of strain M2T2B15 ${ }^{\top}$ is GQ246692.

A supplementary figure is available with the online version of this paper. microbial diversity in Panchakavya. Accordingly, in the present study, we report the taxonomic characterization of strain $\mathrm{M} 2 \mathrm{~T} 2 \mathrm{~B} 15^{\mathrm{T}}$ isolated from modified Panchakavya. The results provide evidence that strain $\mathrm{M} 2 \mathrm{~T} 2 \mathrm{~B} 15^{\mathrm{T}}$ represents a novel species of the genus Larkinella. On the basis of the new chemotaxonomic data obtained from this study, emended descriptions of the genus Larkinella and of Larkinella insperata are also proposed.

The genus Larkinella was first proposed to accommodate a bacterial strain isolated from water of a steam generator in a pharmaceutical company, with Larkinella insperata as the type species (Vancanneyt et al., 2006). According to Ludwig et al. (2008), the genus Larkinella is placed in the family Cytophagaceae, phylum Bacteroidetes. 
Modified Panchakavya was prepared by using the following ingredients: cow dung $\left(1.5 \mathrm{~g} \mathrm{l}^{-1}\right)$, cow urine $\left(4.5 \mathrm{ml} \mathrm{l}^{-1}\right)$, cow's milk $\left(3.0 \mathrm{ml} \mathrm{l}^{-1}\right)$, yogurt $\left(3.0 \mathrm{ml} \mathrm{l}^{-1}\right)$, molasses $\left(4.5 \mathrm{ml} \mathrm{l}^{-1}\right)$ and potato $\left(3.0 \mathrm{~g} \mathrm{l}^{-1}\right)$. The mixture was incubated on a rotary shaker (120 r.p.m.) for 15 days at $30{ }^{\circ} \mathrm{C}$. The cultivable bacteria associated with modified Panchakavya were isolated by using serial dilution plating on trypticase soy agar (TSA), Luria-Bertani agar and R2A agar (all from Difco). Plates were incubated for 4 days at $30{ }^{\circ} \mathrm{C}$. A total of 37 bacterial strains were isolated (data not shown), of which strain M2T2B15 ${ }^{\mathrm{T}}$ appeared on R2A agar and could be distinguished from other bacteria based on its reddish pink colony colour.

Genomic DNA was isolated according to the method described by Ausubel et al. (1987), except that the lysates were extracted twice with chloroform to remove residual phenol. The 16S rRNA gene was amplified by using the universal primers $\mathrm{fD} 1$ and $\mathrm{rP} 2$ (Weisburg et al., 1991), and was sequenced as described by Kwon et al. (2003). The alignment of $16 \mathrm{~S}$ rRNA gene sequences was performed with the CLUSTAL $\mathrm{W}$ program (Thompson et al., 1994) following identification of phylogenetic neighbours via the EzTaxon server (http://www.eztaxon.org/; Chun et al., 2007). Phylogenetic trees were reconstructed with the neighbour-joining (Saitou \& Nei, 1987), maximumparsimony (Fitch, 1971) and maximum-likelihood (Felsenstein, 1981) methods by using the program MEGA3 (Kumar et al., 2004), with bootstrap values based on 1000 replications (Felsenstein, 1985). An almost-complete 16S rRNA gene sequence of strain $\mathrm{M} 2 \mathrm{~T} 2 \mathrm{~B} 15^{\mathrm{T}}$ was obtained (1429 bp). Preliminary comparisons with 16S rRNA gene sequences deposited in the GenBank database indicated that strain $\mathrm{M} 2 \mathrm{~T} 2 \mathrm{~B} 15^{\mathrm{T}}$ belongs to the family Cytophagaceae, phylum Bacteroidetes. 16S rRNA gene sequence analysis revealed that strain $\mathrm{M} 2 \mathrm{~T} 2 \mathrm{~B} 15^{\mathrm{T}}$ was related most closely to L. insperata LMG $22510^{\mathrm{T}}$ (94.4\% similarity) and exhibited less than $87 \%$ sequence similarity to other members of the phylum Bacteroidetes. The overall topologies of the phylogenetic trees were similar irrespective of the phylogenetic methods used (data not shown). Strain M2T2B15 ${ }^{\mathrm{T}}$ formed a separate clade from L. insperata LMG $22510^{\mathrm{T}}$, with $100 \%$ bootstrap support (Fig. 1).

Basic phenotypic tests were examined simultaneously for strain M2T2B15 ${ }^{\mathrm{T}}$ and L. insperata LMG $22510^{\mathrm{T}}$ (=KACC $11764^{\mathrm{T}}$ ) by using the same culture conditions. Cell morphology was examined by using phase-contrast (AXIO; Zeiss) and transmission electron (LEO model
$912 \mathrm{AB}$ ) microscopy with cells grown for 3 days on R2A agar at $30{ }^{\circ} \mathrm{C}$. For transmission electron microscopy, cells were negatively stained with $0.5 \%(\mathrm{w} / \mathrm{v})$ uranyl acetate. Gram staining, catalase and oxidase activities, and hydrolysis of CM-cellulose, casein, chitin from crab shells, hypoxanthine, pectin, starch, tyrosine, Tween 20 and xanthine were assessed with the methods described by Smibert \& Krieg (1994). Degradation of DNA was investigated on DNase test agar (Difco) supplemented with $0.01 \%$ toluidine blue (Merck). The presence of flexirubin-type pigments and gliding motility were assessed by using the methods recommended by Bernardet et al. (2002). The $\mathrm{pH}$ range for growth was determined in $\mathrm{R} 2 \mathrm{~A}$ broth at $30{ }^{\circ} \mathrm{C}$. The $\mathrm{pH}$ of the medium was adjusted with citrate phosphate buffer or Tris/HCl buffer (Breznak \& Costilow, 1994) to $\mathrm{pH} 4.0-10.0$ at increments of $1.0 \mathrm{pH}$ unit. Growth at 5,10,15, 20,30, 35, 40 and $45{ }^{\circ} \mathrm{C}$ was measured in R2A broth. Salt tolerance was tested in R2A broth supplemented with $0,1,2,3,4,5,6,7,8,9$ and $10 \%$ (w/v) $\mathrm{NaCl}$ after 7 days of incubation at $30{ }^{\circ} \mathrm{C}$. Anaerobic growth on R2A agar was assessed at $30^{\circ} \mathrm{C}$ for 10 days by using a BBL anaerobic jar (Becton Dickinson). The strain was also characterized by using API 20 NE, API ID 32 GN and API ZYM test strips (bioMérieux), according to the manufacturer's recommendations. Susceptibility to the antibiotics rifampicin, ampicillin, oleandomycin, chloramphenicol, tetracycline, novobiocin, streptomycin, spectinomycin, kanamycin, trimethoprim, hygromycin, polymyxin $\mathrm{B}$ and nystatin (each at $50 \mu \mathrm{g} \mathrm{ml}^{-1}$ ) was tested on R2A agar plates. Three-day-old colonies of strain $\mathrm{M} 2 \mathrm{~T} 2 \mathrm{~B} 15^{\mathrm{T}}$ grown on $\mathrm{R} 2 \mathrm{~A}$ agar were reddish pink and circular with entire margins. Cells were strictly aerobic, Gram-reaction-negative, oxidase- and catalase-positive rods that lacked flagella but were motile by gliding. Strain $\mathrm{M} 2 \mathrm{~T} 2 \mathrm{~B} 15^{\mathrm{T}}$ could be differentiated from $L$. insperata LMG $22510^{\mathrm{T}}$ on the basis of colony colour, cell shape, hydrolysis of CM-cellulose and tyrosine, and assimilation of D-glucose, L-arabinose, D-mannitol, $\mathrm{N}$-acetylglucosamine, sucrose and salicin. Other differentiating characteristics between strain $\mathrm{M} 2 \mathrm{~T} 2 \mathrm{~B} 15^{\mathrm{T}}$ and L. insperata LMG $22510^{\mathrm{T}}$ are listed in Table 1.

Cellular fatty acid methyl esters were prepared from cells of strain M2T2B15 ${ }^{\mathrm{T}}$ and L. insperata LMG $22510^{\mathrm{T}}$ grown on R2A agar for 3 days at $30^{\circ} \mathrm{C}$, and were analysed by GC according to the instructions of the Microbial Identification System (MIDI). The isoprenoid quinones of strain M2T2B15 ${ }^{\mathrm{T}}$ were analysed by HPLC as described by Groth et al. (1996). The polar lipid profiles of strain

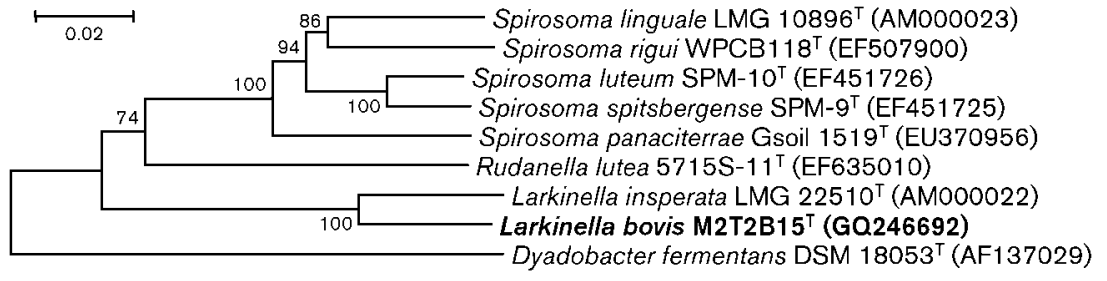

Fig. 1. Neighbour-joining tree based on almost-complete 16S rRNA gene sequences showing the phylogenetic position of strain $\mathrm{M}^{2} \mathrm{~T}_{2} \mathrm{~B} 15^{\top}$. Numbers at nodes indicate percentages of 1000 bootstrap resamplings; only values $>70 \%$ are given. Bar, 0.02 substitutions per nucleotide position. 
Table 1. Differential characteristics between strain M2T2B15 ${ }^{\top}$ and Larkinella insperata LMG $22510^{\top}$

Strains: $1, \mathrm{M} 2 \mathrm{~T} 2 \mathrm{~B} 15^{\mathrm{T}} ; 2$, L. insperata LMG $22510^{\mathrm{T}}$. The two strains hydrolyse aesculin, starch and Tween 20 but not casein, chitin, DNA, hypoxanthine, pectin, gelatin or xanthine. They are negative for the Gram reaction, nitrate reduction, indole production and glucose fermentation. The two strains assimilate maltose, glycogen and melibiose, but not D-mannose, potassium gluconate, capric acid, adipic acid, malic acid, trisodium citrate, phenylacetic acid, L-rhamnose, Dribose, inositol, itaconic acid, suberic acid, sodium malonate, sodium acetate, lactic acid, L-alanine, potassium 5-ketogluconate, 3-hydroxybenzoic acid, L-serine, L-fucose, D-sorbitol, propionic acid, valeric acid, L-histidine, potassium 2-ketogluconate, 3-hydroxybutyric acid, 4hydroxybenzoic acid or L-proline. They are positive for gliding motility, and catalase, oxidase, $\beta$-galactosidase, leucine arylamidase, naphtholAS-BI-phosphohydrolase and $N$-acetyl- $\beta$-glucosaminidase activities. They are negative for esterase lipase (C8), lipase (C14), valine arylamidase, cystine arylamidase, $\alpha$-chymotrypsin, $\beta$-galactosidase, $\beta$ glucuronidase, $\alpha$-glucosidase, $\beta$-glucosidase, $\alpha$-mannosidase, $\alpha$-fucosidase, arginine dihydrolase and urease activities. The two strains are susceptible to rifampicin, ampicillin and novobiocin, but resistant to streptomycin, spectinomycin, kanamycin, trimethoprim, hygromycin and nystatin. All the data were obtained from this study. + , Positive; -, negative; $\mathrm{W}$, weakly positive; $\mathrm{s}$, sensitive; $\mathrm{R}$, resistant.

\begin{tabular}{|c|c|c|}
\hline Characteristic & 1 & 2 \\
\hline Colony colour on R2A agar & $\begin{array}{l}\text { Reddish } \\
\text { pink }\end{array}$ & Pale pink \\
\hline $\begin{array}{l}\text { Cell morphology on R2A agar, cultured } \\
\text { for } 3 \text { days at } 30{ }^{\circ} \mathrm{C}\end{array}$ & Rods & $\begin{array}{l}\text { Ring-like and } \\
\text { horseshoe }\end{array}$ \\
\hline Temperature range for growth $\left({ }^{\circ} \mathrm{C}\right)$ & $10-35$ & $10-40$ \\
\hline $\mathrm{NaCl}$ range for growth (\%) & $0-1$ & $0-3$ \\
\hline \multicolumn{3}{|l|}{ Hydrolysis of: } \\
\hline CM-cellulose & + & - \\
\hline Tyrosine & + & - \\
\hline \multicolumn{3}{|l|}{ Assimilation of: } \\
\hline D-Glucose & + & - \\
\hline L-Arabinose & + & - \\
\hline D-Mannitol & + & - \\
\hline $\mathrm{N}$-Acetylglucosamine & + & - \\
\hline Sucrose & + & - \\
\hline Salicin & + & - \\
\hline \multicolumn{3}{|l|}{ Enzyme activity (API ZYM) } \\
\hline Alkaline phosphatase & + & - \\
\hline Esterase (C4) & - & + \\
\hline Trypsin & $\mathrm{w}$ & - \\
\hline Acid phosphatase & $\mathrm{w}$ & - \\
\hline$\alpha$-Galactosidase & - & $\mathrm{w}$ \\
\hline \multicolumn{3}{|l|}{ Response to antibiotics $\left(50 \mu \mathrm{g} \mathrm{ml}^{-1}\right)$} \\
\hline Oleandomycin & S & $\mathrm{R}$ \\
\hline Chloramphenicol & s & $\mathrm{R}$ \\
\hline Tetracycline & S & $\mathrm{R}$ \\
\hline Polymyxin B & $\mathrm{R}$ & S \\
\hline
\end{tabular}

M2T2B15 ${ }^{\mathrm{T}}$ and L. insperata LMG $22510^{\mathrm{T}}$ were determined according to the method of Minnikin et al. (1984). The DNA G $+C$ content of strain M2T2B15 ${ }^{\mathrm{T}}$ was determined by HPLC of deoxyribonucleosides as described by Mesbah et al. (1989), by using a reversed-phase column (Supelcosil LC-18-S; Supelco). The fatty acid profiles of strain $\mathrm{M} 2 \mathrm{~T} 2 \mathrm{~B} 15^{\mathrm{T}}$ and L. insperata LMG $22510^{\mathrm{T}}$ were almost identical. However, strain M2T2B $15^{\mathrm{T}}$ could be differentiated from L. insperata LMG $22510^{\mathrm{T}}$ based on lower amounts of iso- $\mathrm{C}_{15: 0}(23.9 \%)$ and iso- $\mathrm{C}_{17: 0} 3-\mathrm{OH}(9.9 \%)$, a higher amount of $\mathrm{C}_{16: 1} \omega 5 c(45.5 \%)$ and the absence of summed feature 4 (Table 2). The major respiratory quinone of strain $\mathrm{M} 2 \mathrm{~T} 2 \mathrm{~B} 15^{\mathrm{T}}$ was menaquinone 7 (MK7), in agreement with data for $L$. insperata LMG $22510^{\mathrm{T}}$ (Vancanneyt et al., 2006). Strain $\mathrm{M} 2 \mathrm{~T} 2 \mathrm{~B} 15^{\mathrm{T}}$ and $L$. insperata LMG $22510^{\mathrm{T}}$ displayed similar polar lipid profiles. Their major polar lipids were phosphatidylethanolamine, phosphatidylserine, two unidentified aminophospholipids and two unidentified polar lipids (see Supplementary Fig. S1 in IJSEM Online). The DNA $\mathrm{G}+\mathrm{C}$ content of strain $\mathrm{M} 2 \mathrm{~T} 2 \mathrm{~B} 15^{\mathrm{T}}$ was $52 \mathrm{~mol} \%$, a value close to that reported for $L$. insperata LMG $22510^{\mathrm{T}}$ (53 mol\%; Vancanneyt et al., 2006). On the basis of the phenotypic and phylogenetic data presented, we propose that strain $\mathrm{M} 2 \mathrm{~T} 2 \mathrm{~B} 15^{\mathrm{T}}$ represents a novel species of the genus Larkinella, for which the name Larkinella bovis sp. nov. is proposed. Also, emended descriptions of the genus Larkinella and of Larkinella insperata Vancanneyt et al. 2006 are provided.

Table 2. Cellular fatty acid compositions (\%) of strain M2T2B15 ${ }^{\top}$ and Larkinella insperata LMG $22510^{\top}$

Strains: 1, M2T2B15 ${ }^{\mathrm{T}} ; 2$, L. insperata LMG $22510^{\mathrm{T}}$. Fatty acids amounting to $<1 \%$ of the total fatty acids in both strains are not shown. tr, Trace $(<1 \%)$; - , not detected. Prior to fatty acid extraction the two strains were cultivated on R2A agar medium for 3 days at $30{ }^{\circ} \mathrm{C}$.

\begin{tabular}{|c|c|c|}
\hline Fatty acid & 1 & 2 \\
\hline iso- $\mathrm{C}_{15: 0}$ & 23.9 & 32.2 \\
\hline iso- $\mathrm{C}_{15: 0} 3-\mathrm{OH}$ & 1.2 & 1.2 \\
\hline anteiso- $\mathrm{C}_{15: 0}$ & 2.5 & 1.6 \\
\hline $\mathrm{C}_{16: 0}$ & 3.2 & 4.1 \\
\hline $\mathrm{C}_{16: 0} 3-\mathrm{OH}$ & 1.6 & $\operatorname{tr}$ \\
\hline $\mathrm{C}_{16: 1} \omega 5 c$ & 45.5 & 29.6 \\
\hline iso- $\mathrm{C}_{17: 0}$ & 1.6 & 3.3 \\
\hline iso- $\mathrm{C}_{17: 0} 3-\mathrm{OH}$ & 9.9 & 15.3 \\
\hline Summed feature $3^{*}$ & 5.1 & 2.3 \\
\hline Summed feature $4^{*}$ & - & 1.7 \\
\hline Unknown ECL $13.565 \dagger$ & 4.6 & 5.6 \\
\hline Unknown ECL $16.852 \dagger$ & 1.0 & 1.8 \\
\hline
\end{tabular}

*Summed features are groups of two or three fatty acids that cannot be separated by GLC with the MIDI system. Summed feature 3 comprised $\mathrm{C}_{16: 1} \omega 7 \mathrm{c}$ and/or iso- $\mathrm{C}_{15: 0}$ 2-OH. Summed feature 4 comprised iso- $\mathrm{C}_{17: 1}$ and/or anteiso- $\mathrm{C}_{17: 1} \mathrm{~B}$.

$\dagger$ Unknown fatty acids are designated by their equivalent chain-length (ECL). 


\section{Emended description of the genus Larkinella Vancanneyt et al. 2006}

The description remains as given by Vancanneyt et al. (2006) with the following additions. The predominant polar lipids are phosphatidylethanolamine, phosphatidylserine, two unidentified aminophospholipids and two unidentified polar lipids. The DNA G $+\mathrm{C}$ content is $52-$ $53 \mathrm{~mol} \%$. The genus is a member of the family Cytophagaceae, phylum Bacteroidetes.

\section{Emended description of Larkinella insperata Vancanneyt et al. 2006}

The description remains as given by Vancanneyt et al. (2006) with the following additions or modifications. Growth occurs on TSA, R2A agar and nutrient agar but not on MacConkey agar. Hydrolyses aesculin and starch, but not hypoxanthine, pectin, gelatin or xanthine. Negative for glucose fermentation. Assimilates maltose, glycogen and melibiose but not D-mannose, potassium gluconate, capric acid, adipic acid, malic acid, phenylacetic acid, L-rhamnose, D-ribose, inositol, itaconic acid, suberic acid, sodium malonate, sodium acetate, lactic acid, L-alanine, potassium 5-ketogluconate, 3-hydroxybenzoic acid, L-serine, L-fucose, propionic acid, valeric acid, L-histidine, potassium 2ketogluconate, 3-hydroxybutyric acid, 4-hydroxybenzoic acid, L-proline, D-glucose, L-arabinose, D-mannitol, $\mathrm{N}$ acetylglucosamine, sucrose or salicin. Positive for esterase (C4), leucine arylamidase, naphthol-AS-BI-phosphohydrolase and $N$-acetyl- $\beta$-glucosaminidase activities. Negative for alkaline phosphatase, esterase lipase (C8), trypsin, acid phosphatase, lipase (C14), valine arylamidase, cystine arylamidase, $\alpha$-chymotrypsin, $\beta$-glucuronidase, $\alpha$-glucosidase, $\beta$-glucosidase, $\alpha$-mannosidase, $\alpha$-fucosidase, arginine dihydrolase, $\alpha$-galactosidase, $\beta$-galactosidase and urease activities. Susceptible to rifampicin, ampicillin, polymyxin $\mathrm{B}$ and novobiocin, but resistant to streptomycin, oleandomycin, chloramphenicol, tetracycline, spectinomycin, kanamycin, trimethoprim, hygromycin and nystatin.

\section{Description of Larkinella bovis sp. nov.}

Larkinella bovis (bo'vis. L. gen. n. bovis of a cow, of bovine).

Cells are strictly aerobic, Gram-reaction-negative, oxidaseand catalase-positive rods $(1.2-3.2 \mu \mathrm{m}$ long and 0.9 $1.2 \mu \mathrm{m}$ wide), that lack flagella and are motile by gliding. Colonies on R2A agar are reddish pink, and convex with entire margins. Flexirubin-type pigments are not produced. Optimum growth occurs at $30{ }^{\circ} \mathrm{C}$ and $\mathrm{pH}$ 7.0. The temperature, $\mathrm{pH}$ and $\mathrm{NaCl}$ concentration ranges for growth are $10-35{ }^{\circ} \mathrm{C}, \mathrm{pH} 6.0-7.0$ and $0-1 \%$. Growth occurs on TSA, R2A agar and nutrient agar but not on MacConkey agar. Hydrolyses CM-cellulose, tyrosine, aesculin, starch and Tween 20, but not casein, chitin, DNA, hypoxanthine, pectin, gelatin or xanthine. Negative for nitrate reduction, indole production and glucose fermentation. Assimilates D-glucose, L-arabinose, D-mannitol,
$\mathrm{N}$-acetylglucosamine, sucrose, salicin, maltose, glycogen and melibiose, but not D-mannose, potassium gluconate, capric acid, adipic acid, malic acid, trisodium citrate, phenylacetic acid, L-rhamnose, D-ribose, inositol, itaconic acid, suberic acid, sodium malonate, sodium acetate, lactic acid, L-alanine, potassium 5-ketogluconate, 3-hydroxybenzoic acid, L-serine, L-fucose, D-sorbitol, propionic acid, valeric acid, L-histidine, potassium 2-ketogluconate, 3hydroxybutyric acid, 4-hydroxybenzoic acid or L-proline. Positive for alkaline phosphatase, $\beta$-galactosidase, leucine arylamidase, naphthol-AS-BI-phosphohydrolase and $N$ acetyl- $\beta$-glucosaminidase activities. Weakly positive for trypsin and acid phosphatase. Negative for esterase (C4), esterase lipase (C8), lipase (C14), valine arylamidase, cystine arylamidase, $\alpha$-chymotrypsin, $\alpha$-galactosidase, $\beta$ glucuronidase, $\alpha$-glucosidase, $\beta$-glucosidase, $\alpha$-mannosidase, $\alpha$-fucosidase, arginine dihydrolase and urease activities. Susceptible to rifampicin, ampicillin, oleandomycin, chloramphenicol, tetracycline and novobiocin, but resistant to streptomycin, spectinomycin, kanamycin, trimethoprim, hygromycin, polymyxin $\mathrm{B}$ and nystatin. The major cellular fatty acids are $\mathrm{C}_{16: 1} \omega 5 c$, iso- $\mathrm{C}_{15: 0}$ and iso- $\mathrm{C}_{17: 0} 3-\mathrm{OH}$. The detailed fatty acid composition of the type strain is given in Table 2 . The DNA G $+\mathrm{C}$ content of the type strain is $52 \mathrm{~mol} \%$.

The type strain, M2T2B15 ${ }^{\mathrm{T}}\left(=\mathrm{KACC} 14040^{\mathrm{T}}=\mathrm{NBRC}\right.$ $106324^{\mathrm{T}}$ ), was isolated from fermented bovine products, Suwon, Republic of Korea.

\section{Acknowledgements}

This work was supported by the National Academy of Agricultural Science (NAAS), and the Rural Development Administration (RDA), Republic of Korea. R. A. thanks RDA for award of a postdoctoral fellowship.

\section{References}

Ausubel, F. M., Brent, R., Kingston, R. E., Moore, D. D., Seidman, J. G., Smith, J. A. \& Struhl, K. (editors) (1987). Current Protocols in Molecular Biology. New York: Greene/Wiley Interscience.

Belina, E., David, P. M. M. \& Pillai, M. A. K. (2005). Effect of Cow's-five (Panchakavya) on Spodoptera litura and Liriomyza trifolii. Madras Agric J 92, 595-598.

Bernardet, J.-F., Nakagawa, Y. \& Holmes, B. (2002). Proposed minimal standards for describing new taxa of the family Flavobacteriaceae and emended description of the family. Int J Syst Evol Microbiol 52, 1049-1070.

Breznak, J. A. \& Costilow, R. N. (1994). Physiological factors in growth. In Methods for General and Molecular Bacteriology, pp. 137154. Edited by P. Gerhardt, R. G. E. Murray, W. A. Wood \& N. R. Krieg. Washington, DC: American Society for Microbiology.

Chun, J., Lee, J.-H., Jung, Y., Kim, M., Kim, S., Kim, B. K. \& Lim, Y.-W. (2007). EzTaxon: a web-based tool for the identification of prokaryotes based on 16S ribosomal RNA gene sequences. Int J Syst Evol Microbiol 57, 2259-2261.

Felsenstein, J. (1981). Evolutionary trees from DNA sequences: a maximum likelihood approach. J Mol Evol 17, 368-376. 
Felsenstein, J. (1985). Confidence limits on phylogenies: an approach using the bootstrap. Evolution 39, 783-791.

Fitch, W. M. (1971). Toward defining the course of evolution: minimum change for a specific tree topology. Syst Zool 20, 406-416.

Groth, I., Schumann, P., Weiss, N., Martin, K. \& Rainey, F. A. (1996). Agrococcus jenensis gen. nov., sp. nov., a new genus of actinomycetes with diaminobutyric acid in the cell wall. Int J Syst Bacteriol 46, 234239.

Kumar, S., Tamura, K. \& Nei, M. (2004). MEGA3: integrated software for molecular evolutionary genetics analysis and sequence alignment. Brief Bioinform 5, 150-163.

Kwon, S. W., Kim, J. S., Park, I. C., Yoon, S. H., Park, D. H., Lim, C. K. \& Go, S. J. (2003). Pseudomonas koreensis sp. nov., Pseudomonas umsongensis sp. nov. and Pseudomonas jinjuensis sp. nov., novel species from farm soils in Korea. Int J Syst Evol Microbiol 53, 21-27.

Ludwig, W., Euzéby, J. \& Whitman, W. B. (2008). Draft taxonomic outline of the Bacteroidetes, Planctomycetes, Chlamydiae, Spirochaetes, Fibrobacteres, Fusobacteria, Acidobacteria, Verrucomicrobia, Dictyoglomi, and Gemmatimonadetes for volume 4 of the second edition of Bergey's Manual of Systematic Bacteriology (http://www.bergeys.org/outlines. html).

Mesbah, M., Premachandran, U. \& Whitman, W. B. (1989). Precise measurement of the $\mathrm{G}+\mathrm{C}$ content of deoxyribonucleic acid by highperformance liquid chromatography. Int J Syst Bacteriol 39, 159-167.

Minnikin, D. E., O'Donnell, A. G., Goodfellow, M., Alderson, G., Athalye, M., Schaal, A. \& Parlett, J. H. (1984). An integrated procedure for the extraction of bacterial isoprenoid quinones and polar lipids. J Microbiol Methods 2, 233-241.

Saitou, N. \& Nei, M. (1987). The neighbor-joining method: a new method for reconstructing phylogenetic trees. Mol Biol Evol 4, 406425.

Smibert, R. M. \& Krieg, N. R. (1994). Phenotypic characterization. In Methods for General and Molecular Bacteriology, pp. 607-654. Edited by P. Gerhardt, R. G. E. Murray, W. A. Wood \& N. R. Krieg. Washington, DC: American Society for Microbiology.

Somasundaram, E., Amanullah, M. M., Thirukkumaran, K., Chandrasekaran, R., Vaiyapuri, K. \& Sathyamoorthi, K. (2007). Biochemical changes, nitrogen flux and yield of crops due to organic sources of nutrients under maize based cropping system. J Appl Sci Res 3, 1724-1729.

Thompson, J. D., Higgins, D. G. \& Gibson, T. J. (1994). Clustal W: improving the sensitivity of progressive multiple sequence alignment through sequence weighting, position-specific gap penalties and weight matrix choice. Nucleic Acids Res 22, 4673-4680.

Vancanneyt, M., Nedashkovskaya, O. I., Snauwaert, C., Mortier, S., Vandemeulebroecke, K., Hoste, B., Dawyndt, P., Frolova, G. M., Janssens, D. \& Swings, J. (2006). Larkinella insperata gen. nov., sp. nov., a bacterium of the phylum 'Bacteroidetes' isolated from water of a steam generator. Int J Syst Evol Microbiol 56, 237-241.

Weisburg, W. G., Barns, S. M., Pelletier, D. A. \& Lane, D. J. (1991). $16 \mathrm{~S}$ ribosomal DNA amplification for phylogenetic study. J Bacteriol 173, 697-703. 